\title{
Legal regime of auditors and financial auditors in the matter of companies
}

\author{
George-Bogdan IONIȚ Ă \\ Bucharest University of Economic Studies, Bucharest, Romania \\ ionita.bogdan.george@gmail.com
}

\begin{abstract}
This research aims to analyze one of the most important components of the activity of a company, namely the activity of management control. The paper is structured in three parts, thus aiming to achieve an objective synthesis that faithfully reflects the current structure and regulation of the company's management control. The first part will address the introductory and general aspects of management control according to each type of company, respectively, the rules applicable to partnerships, capital companies but also limited liability companies. The second part of the paper aims to present in a timely manner all the essential aspects regarding the censors, as corporate control bodies. Thus, the analysis following aspects such as the term of office, the rights and obligations of auditors in relation to the company but also their responsibility for the activity carried out. The third part exhaustively analyzes the legal regime of financial auditors and in this sense will prefer to follow the regulation of the company law but also of the special applicable legislation. In carrying out this research, specialized works in the field of society were used, as well as the regulations from the updated special legislation.
\end{abstract}

Keywords: management control, auditors, financial auditors, companies, mandate, audit contract, companies.

\section{Introductory aspects regarding the control of the company's management}

Control of the company's management is an essential activity in the life of any company that seeks both compliance with all rules in the economic sphere of the company and the efficiency of the activity carried out.

Considering that in Romania the matter of companies is regulated by law 31/1990, consequently the rules on the operation and control of the company's management will be found in the same normative act (Cărpenaru, Piperea \& David, 2014, p. 2).

The control activity of the company is regulated differently depending on the type of company, so in the case of partnerships, the control of the activity is performed by all partners, except those who have the status of administrator.

In the case of capital companies, the control is performed by certain persons specialized in this field, such as auditors or financial auditors.

However, we find a special situation in the case of the limited liability company, where it is provided that if the number of partners is not more than 15 , the control of management can be performed by them or by auditors, if this has been stipulated. by the articles of association or if this was subsequently decided by a decision of the general meeting of shareholders. However, if the number of associates is greater than 15, either the appointment of auditors or the appointment of financial auditors is mandatory.

The need to appoint financial auditors is necessary in the case of companies subject to legal auditing obligations such as the situation of joint stock companies that opt for the dual management system. 
In other cases, the ordinary general meeting of shareholders is the decision-making body that will decide either the appointment of auditors or the appointment of financial auditors (Nemeş, 2018, p.168).

In conclusion, in the case of the control activity of the company's management, there is the possibility that this activity is performed even by the associates (in the cases and conditions provided by law) or by specialized bodies such as auditors or financial auditors.

PICBE | 937

\section{Control of the company's management through auditors}

Auditors are specialized control bodies that have the competence to verify the way in which the administrators managed the activity of a company, including the legality of the preparation of the financial statements of the economic entity (Gheorghe, 2013, p. 403).

In the case of a joint stock company and a limited partnership which is not subject to the legal obligation to audit, they will have three auditors and an alternate, unless the articles of incorporation provide for a larger number. There must be an odd number of censors must be odd.

In the case of limited liability companies whose annual financial statements are not subject to the statutory audit obligation, they may have one or more auditors in accordance with the provisions laid down in the articles of association. As mentioned above, the obligation to appoint auditors arises if in the case of a limited liability company the number of partners is greater than 15. If the partners have not opted for the appointment of auditors or financial auditors, each of the partners, who is not a director, will be able to exercise the right to control the management of the company.

Therefore, the first auditors are appointed by the articles of association of the company, the associates having the obligation to indicate their identification data. If the censors were not appointed by the articles of association of the company, subsequently, they can be elected by the ordinary general meeting under the conditions established by law (Angheni, 2013, p. 205).

A special regulation can be found in joint stock companies with majority state capital in which it is mandatory to appoint one of the auditors as a representative of the Ministry of Economy and Finance.

The term of office of the censors is three years and they can be re-elected.

With regard to persons who may be auditors, it is provided that they may be associated, with the exception of the accounting expert censor who may be a third party and who exercises the profession individually or in associative forms. Moreover, no censors can be elected, and if relatives or relatives-in-law up to the fourth degree or the spouses of administrators have been elected, for the duration of their term of office, persons who receive, in any form, for positions other than that of censor, a salary or a remuneration from the directors or the company whose employers are in contractual relations or are in competition with it, the persons who are prohibited from the position of member of the board of directors, respectively of the supervisory board and the management, persons who the duration of the exercise of the attributions conferred by this quality, have control attributions within the Ministry of Public Finance or other public institutions (Piperea, 2020, p. 389).

The relationship between the company and the auditors based on which it operates is one of mandate with a mixed content - legal and conventional (Angheni, 2019, p. 296).

The activity carried out by the auditors is remunerated, having a fixed amount, established by the constitutive act or by the decision of the general assembly by which they were appointed. 
The revocation of the auditors is made in the extraordinary general meeting of shareholders atypically compared to their appointment which can be achieved by the ordinary or extraordinary general meeting and without imposing quorum conditions and special majority. Their revocation may be without just cause and in this case they opened the possibility of notifying the court in order to request the obligation of the company to pay compensation (Nasz, 2019, p. 192).

In the event of death, legal or physical impossibility, termination or resignation of a censor, he may be replaced by an alternate. In the mentioned situation or in case the legal number of censors cannot be completed by replacing with substitutes or no censor remains in office, the administrators will convene the general meeting in order to appoint a new censor.

Any change in the auditors must be recorded in the trade register by the board of directors or the directorate. The same situation must be taken into account for financial auditors with the exception of internal auditors.

With regard to the obligations of auditors, they are mainly obliged to supervise the management of the company, to verify the legality of the financial statements prepared in accordance with the registers, to verify that the company's registers are legally kept and that the valuation of objects in the company's patrimony was carried out. , thus presenting a report to the general meeting of shareholders which will also include their proposal in connection with the financial statements prepared but also on the distribution of profit. Equally, the auditors are obliged to inform the administrators but also the general meeting all the irregularities identified in the administration of the company as well as the violations of the articles of association that they find after the verifications (Cărpenaru, 2014, p. 232).

The auditors are also obliged not to disclose to private shareholders or third parties details of the company's operations during the term of office entrusted. The company's shareholders have the possibility to complain to the auditors certain facts or circumstances about which they believe that auditors should be subject to audits in order to prepare the report to the general meeting. According to art. $164^{1}$ of Law no. $31 / 1990$ stipulates that If the complaint is made by shareholders representing, individually or together, at least $5 \%$ of the share capital or a lower share, if the articles of association so provide, the auditors are obliged to check. If they consider that the complaint is well-founded and urgent, they are obliged to convene the general meeting immediately and to submit their observations to it. Otherwise, they must discuss the complaint at the first meeting. The general assembly must take a decision on those claimed.

The auditors are also obliged to fulfill their personal mandate and will draw up reports to be presented at the general assembly. If there are disagreements regarding the preparation of the report, each auditor has the obligation to prepare a separate report and present it to the general assembly. Last but not least, the auditors are obliged to enter in a special register their deliberations but also the findings made during the exercise of the mandate.

With regard to the rights of auditors, they are essentially entitled to obtain from the directors a monthly statement regarding the company's activity. Auditors are also entitled to attend board meetings only when convened by the chairman of the board or if the auditors request to attend meetings in order to obtain further clarification on issues that fall within their scope of verification. If the censors participate in the meetings of the company, in all cases they do not have the right to vote on the issues debated by the statutory bodies (Piperea, 2012, p. 246).

Regarding the liability of the auditors, the scope and effects are grafted on the rules of the mandate and as a consequence the auditors will be held civilly or criminally liable for the way in which they fulfilled their obligations received from the general assembly. As per civil liability, 
the auditors are jointly and severally liable for the damages caused to the company by the harmful activity carried out.

Regarding criminal liability, there are special provisions in law no. 31/1990 on crimes that can be committed by censors as active subjects.

Thus, according to art. 276, the censor who does not convene the general assembly in cases where he is obliged by law shall be punished by imprisonment between one month to one year or by a fine.

Art. 277 stipulates that the person who accepted or kept the task of censor or the person who accepted the task of expert shall be punished by imprisonment between three and twelve months or by a fine. Decisions taken by general meetings on the basis of a report by a censor or expert may not be annulled on account of a breach of the provisions contained in those articles.

The provided penalty shall also punish the founder, administrator, director, executive director or censor who exercises his functions or duties in violation of the provisions of this law regarding incompatibility.

\section{Control of the company's management through financial auditors}

The financial audit activity in Romania is regulated by GEO 75/1999, amended by law no. $162 / 2017$ on the statutory audit of the annual financial statements and of the consolidated annual financial statements and amending some normative acts.

The law on commercial companies establishes in art.160 that joint stock companies that choose, from the establishment or later, during the operation, by decision of the extraordinary general meeting to be managed by a director and a supervisory board, are subject to financial audit. Therefore, under the conditions established by art. 160, the financial statements of the companies will be audited by financial auditors, who may be natural or legal persons.

Likewise, the law also stipulates that all companies whose annual financial statements are subject to financial audit, according to the law or the shareholders' decision are obliged to organize the internal audit according to the norms prescribed by the Romanian Chamber of Financial Auditors. The company subject to the legal audit obligation must also appoint internal auditors.

It is also possible that in the case of companies that are not subject to financial audit, by the will of the general meeting to use financial auditors or to appoint auditors.

The financial audit is the activity carried out by the financial auditors in order to express an opinion on the financial statements or of some of their components, the exercise of other insurance missions and professional services, in accordance with the special regulation in the matter. According to law no. 162/2007, the financial audit includes the statutory audit as well as the activity performed in order to express an opinion on the financial statements or some of their components, but also the exercise of other insurance missions and professional services according to international auditing standards and other regulations.

The statutory audit means an audit of the individual annual financial statements or of the consolidated annual financial statements performed in accordance with international auditing standards, within the meaning of art. 32, in so far as:

a) is compulsory under European Union law or national law;

b) is performed voluntarily at small entities, and the audited financial statements are published, together with the statutory audit report, according to the law.

The statutory audit is performed by financial auditors or audit firms that are authorized in Romania under the conditions of this law, which are registered as members of the Romanian 
Chamber of Financial Auditors, under the law, and which are registered in the electronic public register provided the art. 14 under the conditions established by this law and by the regulations of the Authority for Public Supervision of the Statutory Audit Activity.

The audit firm is the legal person or any other entity, regardless of its legal form, which is authorized in accordance with the provisions of this law by the Authority for Public Supervision of the Statutory Audit Activity to perform financial audit;

Specifically, their activity concerns the statutory audit of the consolidated financial statements and annual financial statements; the audit of the annual financial statements and the consolidated annual financial statements, if they do not constitute a statutory audit but also missions to review the annual (consolidated) financial statements or assurance missions or other professional missions and services. Last but not least, the activity of auditors may also aim at internal audit, other than public internal audit.

The legal relationship between the company and the financial auditor is based on the statutory audit contract. The statutory audit contract concluded with a financial auditor or an audit firm may be terminated in accordance with the law. Differences of opinion regarding accounting treatments or audit procedures are not a good reason to terminate the contract. The audited entity and the financial auditor or audit firm shall inform the Authority for Public Oversight of the Statutory Audit Activity in writing of the termination of the contract during the term of office or the statutory audit contract and provide an appropriate written explanation for their reasons. In the case of a statutory audit to a public interest entity, it is permitted to submit a complaint to a competent court requesting the revocation of the financial auditor or the termination of the statutory audit contract with the audit firm. The court may be required to oblige the audit firm to revoke the financial auditor appointed by the audit firm to perform a specific statutory audit engagement. The Authority for the Public Supervision of the Statutory Audit Activity may request the revocation of the financial auditor or the termination of the statutory audit contract, as the case may be, if a financial sanction has been applied to the financial auditor or audit firm.

Financial auditors who carry out specific activities in a company must be independent of the audited entity and not be involved in its decision-making process.

Thus art. 21 of Law no. 162/2017 stipulates that in the situation when performing a statutory audit, the financial auditor and / or the audit firm, as well as any natural person in a position to directly or indirectly influence the result of the statutory audit must be independent of the audited entity and not be involved in the decision-making process of the audited entity, within the meaning of the Code of Ethics. Independence is necessary both during the period covered by the audited financial statements and during the period in which the statutory audit is performed. The financial auditor or audit firm shall take all reasonable steps to ensure that, in carrying out its statutory audit, its independence is not influenced by an existing or potential conflict of interest or by business or other direct or indirect relationships that involve the financial auditor or audit firm performing the audit and, where applicable, the network to which it belongs, the executive management staff, auditors, employees and any natural person whose services are available or under the control of the financial auditor or audit firm or any person directly or indirectly linked to the financial auditor or audit firm through a controlling relationship.

From this point of view, a clear distinction must be made between financial auditors (external) and internal auditors. Thus, the internal auditors have the quality of employees of the company and come to the support of the board of directors or the supervisory board in order to prevent fraud and streamline the economic activity of the company. They have the obligation to supervise the management of the company, to verify if the financial statements prepared are legal 
and in accordance with the registers but also the obligation to evaluate the patrimonial elements of the company. In this respect, the coordination of the entire internal audit activity will be carried out under the guidance and responsibility of a financial auditor.

Thus, the external financial auditors are not employees of the company, but only concluded a statutory audit contract that aims to verify the financial statements of the company and their concordance with the financial position of the legal entity, so that shareholders can correctly assess the activity and the performance of the company's administrators.

Similarly as in the case of auditors, the appointment of the first financial auditors takes place by the articles of association, and if the joint stock company is constituted by public subscription, the constituent assembly has the obligation to appoint the first auditors or the first financial auditor. In addition to the provisions of law no. 31/1990, law no. 162/2017 provides in art. 62 that the financial auditor or audit firm is appointed by the general meeting of shareholders or associates of the audited entity. The statutory audit is performed on the basis of the statutory audit contract which is concluded in writing, after the date of appointment of the financial auditor or audit firm by the general meeting of shareholders or associates of the audited entity. Any contractual clause restricting, to certain categories or lists of financial auditors or audit firms, the possibility of the general meeting of shareholders or associates of the audited entity to appoint a specific financial auditor or audit firm to perform the statutory audit of that entity. Any such existing clauses are void. Following the incorporation of the company, the appointment of financial auditors is the responsibility of the ordinary general meeting. Regarding the duration of the assignment of the financial auditors, the law does not impose a certain duration and in this case, the effective duration of the auditors' activity will be established by the partners in the statutory audit contract.

As in the case of auditors and financial auditors, there is an obligation to publicize their appointment or dismissal (revocation), being left to the care of the board of directors or management (Didea, 2015, p. 211). The financial auditors must inform the members of the board of directors or, as the case may be, of the general meeting, of any irregularities they find in the management of the company. in order to be discussed and approved by the general meeting, the financial statement must be accompanied by the financial auditor's report. The financial auditor or audit firm must present the results of the statutory audit in an audit report. The report shall be prepared in accordance with the requirements of the audit standards adopted by the European Union or the Authority for Public Oversight of the Statutory Audit Activity. The audit report shall be in writing and shall include:

a) identification of the entity whose annual or consolidated financial statements are subject to statutory audit by name, registered office and unique identification code; identification of the annual or consolidated financial statements and the date or period for which they were prepared and identification of the financial reporting framework applied to their preparation;

b) a description of the scope of the statutory audit that identifies at least the audit standards according to which the statutory audit was performed;

c) the auditor's opinion, which is either unreserved or unreserved or contrary, and clearly expresses the auditor's or audit firm's views on the following: whether the annual financial statements provide a true and fair view, in accordance with the relevant financial reporting; and, where applicable, whether the annual financial statements comply with the applicable legal requirements. If the auditor or audit firm is unable to issue an audit opinion, the report shall state that it is impossible to issue an opinion; 
d) any other matter on which the financial auditor or audit firm draws particular attention, without changing the audit opinion;

e) the auditor's opinion regarding: the coherence of the directors' report with the financial statements for the same financial year; and preparing the directors' report in accordance with the applicable legal provisions;

f) a statement on the identification of material misstatement of the directors' report, indicating the nature of such misstatement;

g) a statement of any significant uncertainty associated with events or conditions that may significantly call into question the entity's ability to continue to operate;

h) an indication of the seat of the financial auditor or audit firm.

If the statutory audit has been performed by several financial auditors or several audit firms, they shall agree on the results of the statutory audit and submit a joint report and opinion. In case of disagreement, each financial auditor or audit firm shall deliver its opinion in a separate paragraph of the audit report and indicate the reason for the disagreement.

The audit report is signed and dated by the financial auditor. If the statutory audit is performed by an audit firm, the audit report shall be signed by at least the financial auditor who performed the statutory audit on behalf of the audit firm. If several financial auditors or several audit firms have jointly performed the audit of an entity, the audit report shall be signed by all financial auditors or at least by the financial auditors performing the statutory audit on behalf of each audit firm.

The financial auditor who signs the statutory audit report in his own name or on behalf of an audit firm must have the status of active financial auditor.

In exceptional circumstances, regulations issued by the Authority for Public Supervision of the Statutory Audit Activity, approved by order of the President, establish the conditions under which the signature should not be disclosed to the public, if such disclosure could lead to an imminent threat; significant to the personal security of any individual. In any case, the name of the person concerned shall be brought to the attention of the competent supervisory or judicial authority.

The report of the financial auditor or audit firm on the consolidated annual financial statements must comply with the requirements set out above. When reporting on the consistency of the directors' report with the financial statements, the financial auditor or audit firm shall take into account the consolidated annual financial statements and the consolidated report of the directors. Only one audit report may be presented if the parent's annual financial statements are annexed to the consolidated annual financial statements. Moreover, any shareholder has the right to complain to the internal auditors about the facts that he believes should be verified, with the obligation to verify the notifications and to communicate to them the findings made regarding the reported issue. With regard to the liability of the auditors, they will be liable on the civil side for the damages caused to the company with regard to the exercise of the entrusted mandate.

Also by law no. 162/2017 is established an administrative liability of financial auditors.

Thus, according to art. 40 stipulates that the financial auditor and audit firms are administratively liable in the event of misconduct. The administrative misconduct consists in an action or inaction in which the provisions of this law, of the regulations in the field of statutory audit approved under the law or, as the case may be, of Regulation (EU) no. 537/2014. The procedure for ascertaining the administrative deviations, as well as the manner of carrying out the administrative procedure are provided in the regulation of the Disciplinary Commission of the Authority for Public Supervision of the Statutory Audit Activity. 
Following the administrative procedure, the Authority for Public Supervision of the Statutory Audit Activity applies to financial auditors and audit firms one or more of the following sanctions:

a) public warning, in which the sanctioned person and the nature of the violation are identified, published on the website of the Authority for Public Supervision of the Statutory Audit Activity;

b) administrative penalty, between 2 and 6 minimum gross salaries per economy, for financial

PICBE |

943

c) administrative penalty, between $0.5 \%$ and $2.5 \%$ of the annual turnover related to the statutory audit activity, for audit firms;

d) temporary prohibition, between 1 and 3 years, for the financial auditor, audit firm or key audit partner to perform financial audits and / or to sign statutory audit reports;

e) withdrawal of the authorization, accompanied, in the case of natural persons, by the loss of the quality of financial auditor;

f) a temporary ban of up to 3 years for a member of the audit firm or a member of the administrative or management body of a public-interest entity to perform functions in audit firms or public-interest entities.

If the financial auditor is convicted by a final decision for criminal offenses related to the exercise of the financial audit activity or he is subject to the additional penalty of being prohibited from carrying out such activity or the security measure is exercised, will communicate a copy of the court decision to the Authority for Public Supervision of the Statutory Audit Activity, in order to operate the withdrawal of the authorization and its deregistration from the Electronic Public Register. The Authority for the Public Supervision of the Statutory Audit Activity follows the stage of carrying out the criminal actions directed against the statutory auditors.

\section{Conclusions}

The object of this research was to analyze the main forms of control of the company's management in the light of specific company legislation.

Thus, a first issue concerns the fact that, compared to the forms of company regulated by law 31/1990 we find non-unitary rules of management control, a situation that can be explained by the differences between the types of companies, where for example in the case of partnerships, management control is it is done by the associates, without the need to appoint auditors or financial auditors.

A second issue highlights the differentiation of the legal status of specialized control bodies (auditors and financial auditors), where as can be seen lies primarily in the relationships that are established between the company and the specialized control bodies.

Therefore, in the case of auditors we discuss relationships based on a mandate contract (similar to the relationship between administrator and company) and in the case of financial auditors we discuss a statutory audit contract which essentially differs considerably from a simple mandate contract of auditors. 


\section{References}

Angheni, S. (2013). Drept comercial. Profesioniștii comercianți, București, C.H. Beck.

Angheni, S. (2019). Drept comercial. Tratat, București, C.H. Beck.

Cărpenaru, S. (2014). Tratat de drept comercial. Ediția a V-a, București, Universul Juridic.

Cărpenaru, S., Piperea, Gh., \& David, S. (2014). Legea societăților comerciale. Comentarii pe articole. Ediția a 5-a, București, C.H. Beck.

Didea, I. (2015). Drept comercial, București, Universul Juridic.

PICBE |

944

Gheorghe, C. (2013). Drept comercial român, București, C.H. Beck.

Nasz, C. (2019). Drept societar, București, Universul Juridic.

Nemeș, V. (2018). Drept comercial. Ediția a 3-a, București, Hamangiu.

Piperea, Gh. (2012). Drept comercial român. Intreprinderea, București, C.H. Beck.

Piperea, Gh. (2020). Drept comercial român. Teoria generală, întreprinderea și insolvența, București, C.H. Beck. 